\title{
BMP and Activin Membrane-Bound Inhibitor Homolog
}

National Cancer Institute

\section{Source}

National Cancer Institute. BMP and Activin Membrane-Bound Inhibitor Homolog. NCI

Thesaurus. Code C33973.

BMP and activin membrane-bound inhibitor homolog (260 aa, $29 \mathrm{kDa}$ ) is encoded by the human BAMBI gene. This protein is involved in the inhibition of transforming growth factor-beta family-dependent signaling. 